\title{
Perbandingan Kebijakan Hukum terhadap Tanggung Jawab Transnasional Corporations atas Pelanggaran Hak Menikmati Lingkungan yang Sehat di Beberapa Negara
}

\author{
Sri Wartini dan Jamaludin Ghafur \\ Fakultas Hukum Universitas Islam Indonesia \\ Jl. Tamansiswa No. 158 Yogyakarta \\ sri.wartini67@yahoo.com ; james.fhuii@gmail.com
}

\begin{abstract}
Most TNCs investing in developing countries control the exploitation of natural resources. However, the environmental protection standards applied by TNCs in the home state and the host state are not the same. The bad experiences occuring in some developing countries (Indonesia, India, Ecuador, and Nigeria) trigger various policies to protect the right to enjoy a healthy environment. This study comprehensively analyzes: first, how is the legal policy of the responsibility of TNCs on the right protection to enjoy healthy environment in Indonesia, India, Ecuador, Nigeria and Finland? Second, what are the similarities and differences in its policymaking? This study is a qualitative research with normative and comparative juridical approach. The results of this study concluded that, first, the legal policies of developing countries towards the violation of TNCs responsibilities to enjoy a healthy environment have the same pattern, which is pretty mild in granting sanction, and prioritizing more on the economic growth rather than protecting the right to enjoy healthy environment. Second, the similar legal policy between these countries lies on the fact that they have recognized the right to enjoy healthy environment as a constitutional right and part of human rights. However, the implementation of the legal protection of the right to enjoy healthy environment differs from one country to another.
\end{abstract}

Key words : Political law, there is accountability, violations, TNCs, a healthy environment, and constitutional rights.

\begin{abstract}
Abstrak
Sebagian

Sebagian besar TNCs yang menanamkan modalnya di negara berkembang beroperasi dalam eksploitasi sumber alam. Namun, standar perlindungan lingkungan yang diterapkan TNCs di home state dan host state tidaklah sama. Berdasarkan pengalaman buruk negara berkembang (Indonesia, India, Equador, dan Nigeria), maka muncullah berbagai kebijakan untuk melindungi hak menikmati lingkungan hidup yang sehat. Penelitian ini menganalisa secara komprehensif: Pertama, bagaimana kebijakan hukum terhadap tanggung jawab TNCs atas perlindungan hak untuk menikmati lingkungan yang sehat di Indonesia, India, Equador, Nigeria dan Finlandia? Kedua, apa saja persamaan dan perbedaan dalam pembuatan kebijakan tersebut? Penelitian ini merupakan penelitian kualitatif, dengan pendekatan yuridis normatif dan komparatif. Hasil penelitian ini menyimpulkan, pertama, kebijakan hukum negara berkembang terhadap tanggung jawab TNCs atas pelanggaran hak menikmati lingkungan hidup yang sehat memiliki pola yang sama, yaitu bersifat tidak begitu tegas dalam pemberian sanksinya dan lebih memprioritaskan pertumbuhan ekonomi daripada perlindungan hak menikmati lingkungan hidup yang sehat. Kedua, persamaannya ialah telah diakuinya hak untuk menikmati lingkungan yang sehat sebagai hak konstitusi dan bagian dari hak asasi manusia. Namun demikian, implementasi perlindungan hukum terhadap hak menikmati lingkungan yang sehat berbeda antara negara satu dan lainnya.
\end{abstract}

Kata kunci : Politik hukum, petanggungjawaban, pelanggaran, TNCs, lingkungan yang sehat, dan hak konstitusi. 


\section{Pendahuluan}

Di masa silam, pembangunan dan kelestarian lingkungan seolah dianggap sebagai dua hal yang saling kontradiksi. Banyak orang beranggapan bahwa aktivitas pembangunan pasti akan berdampak pada kerusakan lingkungan, sehingga ada semacam keyakinan bahwa jika ingin menjaga kelestarian lingkungan meniscayakan tidak boleh ada aktivitas pembangunan (eksplorasi sumber daya alam). Sebaliknya, jika memilih pembangunan maka kelestarian lingkungan harus siap untuk dikorbankan.

Saat ini, persepsi tersebut sudah ditinggalkan karena tidak benar antara pembangunan dan kelestarian lingkungan adalah dua hal yang tidak bisa disatukan. Pembangunan dengan konsep berkelanjutan (Sustainability Development) sudah merupakan tren yang dilakukan oleh banyak negara. Artinya, negara-negara di dunia sudah menyadari bahwa harus ada keseimbangan antara pembangunan ekonomi di satu sisi dan tetap menjaga kelestarian lingkungan pada sisi yang lain.

Pada awalnya persoalan kerusakan lingkungan dianggap hanya merupakan persoalan yang dihadapi oleh negara-negara berkembang. Namun demikian, dalam perkembangannya persoalan lingkungan juga melanda negaranegara maju, walaupun faktor penyebab kerusakan lingkungan berbeda antara yang dialami oleh negara berkembang dan negara maju. Menurut Muhammad Akib ${ }^{1}$, masalah lingkungan di negara maju lebih disebabkan oleh kemajuan dan perkembangan teknologi yang pesat, seperti dampak teknologi nuklir dan pencemaran limbah kimia dari perusahaan industri. Sementara di negara berkembang disebabkan oleh keterbelakangan pembangunan dan kemiskinan, yang ditandai oleh rendahnya mutu hidup, kekurangan sandang dan pangan, rendahnya pendidikan, tingkat kesehatan, dan sanitasi yang jauh dari memadai.

Beberapa data menunjukkan betapa kerusakan lingkungan bukanlah monopoli negara berkembang tetapi juga menjadi problem di negara-negara maju; yaitu pada akhir tahun 1953 di Jepang terjadi penyakit mengerikan yang dikenal dengan "penyakit minamata" yang disebabkan karena mengonsumsi ikan yang tercemar oleh 2014, hlm. 15.

${ }^{1}$ Muhammad Akib, Hukum Lingkungan Perspektif Global dan Nasional, Edisi Revisi, Rajawali Pers, Jakarta, 
metilmerkuri dari limbah beberapa pabrik kimia, ${ }^{2}$ ledakan reaktor nuklir Chernobyl, Rusia yang meningkatkan risiko kanker pada manusia, kebocoran pabrik pesticide di Bhopal, India, yang membunuh lebih dari 200 jiwa dan menyebabkan kebutaan lebih dari 200.000 orang, kasus lumpur panas Sidoarjo (PT Lapindo Brantas) dan pencemaran Teluk Buyat oleh PT Newmont Minahasa Raya adalah beberapa contoh kerusakan lingkungan yang terjadi di Indonesia, dan lain-lain.

Untuk mencegah dan mengantisipasi kerusakan lingkungan atas eksplorasi sumber daya alam akibat dari aktifitas pembangunan yang ada, semua negara baik negara berkembang maupun negara maju telah membuat kebijakan sendirisendiri melalui instrumen hukum di masing-masing negaranya. Berbagai aturan dibuat sebagai panduan bagi siapapun yang akan melakukan eksplorasi SDA agar tetap memperhatikan kelestarian lingkungan. Sekalipun setiap negara sudah dapat dipastikan memiliki kebijakan dalam rangka menjaga kelestarian lingkungannya, namun hampir dapat diyakini pula bahwa kebijakan hukum di masing-masing negara tersebut pastilah akan berbeda-beda menyesuaikan dengan kebutuhan masing-masing internal negara.

Menurut Mas Achmad Santosa, jika dilihat dari sudut komitmen negara di dalam menjamin perlindungan lingkungan dapat diklasifikasikan sebagai berikut: (i) Kategori Komitmen Tertinggi; (ii) Kategori Komitmen Tinggi; (iii) Kategori Komitmen Memadai; Kategori Komitmen Sedang; dan (v) Kategori Komitmen Rendah. Komitmen yang dilakukan negara berbeda-beda terhadap perlindungan lingkungan, tergantung dari tujuan masing -masing negara yang ingin diwujudkan. Misalnya saja kalau negara mengacu pada komitmen rendah dalam perlindungan lingkungan maka dalam konstitusinya sama sekali tidak mengakui norma hukum lingkungan (subjective rights maupun duty of the state) maupun pemuatan pola dan arah pembangunan.

Oleh karenanya, menjadi sangat penting untuk dilakukannya riset guna membandingkan bagaimana masing-masing negara membuat kebijakan hukum dalam rangka memastikan agar proses pembangunan bisa berjalan tanpa merusak dan mencemarkan lingkungan.

${ }^{2}$ Otto Soemarwoto, Ekologi, Lingkungan Hidup dan Pembangunan, Djambatan, Bandung, 1991, hlm. 25 


\section{Rumusan Masalah}

Berdasarkan uraian di atas, permasalahan yang menarik untuk dikaji ialah pertama, bagaimana kebijakan hukum terhadap tanggung jawab TNCs atas pelanggaran hak untuk menikmati lingkungan yang sehat di Indonesia, Nigeria, Equador, India, dan Finlandia? Kedua, apa perbedaan dan persamaan kebijakan hukum terhadap tanggung jawab TNCs atas pelanggaran hak untuk menikmati lingkungan yang sehat di Indonesia, Nigeria, Equador, India, dan Finlandia?

\section{Tujuan Penelitian}

Penelitian ini bertujuan, pertama untuk menganalisa kebijakan hukum terhadap tanggung jawab TNCs atas pelanggaran hak untuk menikmati lingkungan yang sehat di Indonesia, Nigeria, Equador, India, dan Finlandia? Kedua, untuk menganalisa apa saja persamaan dan perbedaan kebijakan hukum terhadap tanggung jawab TNCs atas pelanggaran hak untuk menikmati lingkungan yang sehat di Indonesia, Nigeria, Equador, India, dan Finlandia.

\section{Metode Penelitian}

Jenis penelitian ini adalah penelitian hukum normatif. Obyek penelitian ini adalah perbandingan kebijakan hukum terhadap tanggung jawab TNCs atas pelanggaran hak untuk menikmati lingkungan hidup yang sehat di Indonesia, India, Equador, Nigeria dan Finlandia. Teknik pengumpulan bahan hukum dilakukan melalui studi pustaka yakni mengkaji instrumen internasional dan peraturan perundang-undangan Indonesia yang berkaitan dengan kebijakan terhadap tanggung jawab TNCs atas pelanggaran hak menikmati lingkungan hidup yang sehat. Pendekatan yang digunakan adalah pendekatan perundang-undangan (statute approach) dan pendekatan komparatif (comparative approach). Artikel ini dianalisis secara kualitatif, dan dipaparkan dalam bentuk deskriptif analitis. 


\section{Hasil Penelitian dan Pembahasan}

\section{Perbandingan Kebijakan Hukum terhadap Tanggung Jawab Transnasional Corporations Atas Pelanggaran Hak Menikmati Lingkungan yang Sehat di Beberapa Negara}

\section{Kebijakan Hukum terhadap Tanggung Jawab TNCs atas Pelanggaran Hak Menikmati Lingkungan yang Sehat di Indonesia}

Pasal 33 ayat (4) UUD 1945 menyatakan: perekonomian nasional diselenggarakan berdasar atas demokrasi ekonomi dengan prinsip keadilan, kebersamaan, efisiensi, berkelanjutan, berwawasan lingkungan, kemandirian, serta dengan menjaga keseimbangan kemajuan dan kesatuan ekonomi nasional. Ketentuan Pasal 33 UUD 1945 ini menyiratkan bahwa penyelenggaraan perekonomian nasional harus diselenggarakan berdasar atas demokrasi ekonomi dengan beberapa prinsip diantaranya adalah prinsip berkelanjutan, berwawasan lingkungan, dan keseimbangan kemajuan. Selain itu, Pasal 33 UUD 1945 tersebut juga mengkaitkan antara pembangunan ekonomi nasional dengan lingkungan hidup. Jadi, prinsip dasar pembangunan yang dianut sekarang ini harus dapat menyelaraskan pembangunan ekonomi, sosial, maupun lingkungan secara baik dan harmonis.

Selain Pasal 33, pasal lain yang berkaitan dengan jaminan konstitusional hak atas lingkungan hidup yang sehat diatur pula dalam Pasal $28 \mathrm{H}$ ayat (1) UUD 1945: Setiap orang berhak hidup sejahtera lahir dan batin, bertempat tinggal, dan mendapatkan lingkungan hidup yang baik dan sehat serta berhak memperoleh pelayanan kesehatan. Hadirnya ketentuan Pasal 28H ayat (1) UUD 1945 tersebut telah menegaskan bahwa norma lingkungan hidup telah mengalami konstitusionalisasi menjadi materi muatan konstitusi sebagai hukum tertinggi. Dengan demikian, segala kebijakan, tindakan pemerintah dan pembangunan haruslah tunduk pada ketentuan mengenai hak asasi manusia atas lingkungan hidup yang baik dan sehat itu. Tidak boleh ada lagi kebijakan yang tertuang dalam bentuk undangundang ataupun peraturan di bawah undang-undang yang bertentangan dengan ketentuan konstitusional yang pro-lingkungan ini. Apalagi, Indonesia sendiri merupakan satu negara kepulauan yang sangat rentan dan rawan bencana alam. 
Jika lingkungan hidup tidak dilindungi, pada saatnya, kerusakan alam yang terjadi justru akan merugikan bangsa Indonesia sendiri. ${ }^{3}$

Dengan demikian, secara konstitusional Pasal 33 dan Pasal 28H ayat (1) UUD 1945 merupakan acuan dan tujuan yang ingin di capai dalam pengelolaan lingkungan di Indonesia yaitu pengelolaan lingkungan demi sebesar-besarnya kepentingan dan kemakmuran masyarakat Indonesia dengan tetap menjaga kelestarian alam. Oleh sebab itu, UUD 1945 sebagai hukum tertinggi di Indonesia harus dijadikan pedoman pokok di dalam mendesain kebijakan hukum tentang lingkungan di Indonesia. Menurut Jimly Asshiddiqie, adanya unsur-unsur kebijakan yang pro lingkungan di dalam UUD 1945 itu menjadikan UUD 1945 sebagai salah satu green constitution di dunia, meskipun nuansa hijau masih sangat tipis (light green constitution). ${ }^{4}$

Sekalipun UUD 1945 dapat disebut sebagai salah satu green constitution di dunia, ditinjau dari sudut komitmen negara-negara di dalam menjamin perlindungan lingkungan yang diklasifikasikan ke dalam 5 (lima) kategori yaitu: kategori komitmen tertinggi, kategori komitmen tinggi, kategori komitmen memadai, kategori komitmen sedang, dan kategori komitmen rendah, menurut Mas Achmad Santosa, komitmen bangsa Indonesia di dalam menjamin perlindungan lingkungan masih dalam kategori sedang (kelompok keempat), karena mengakui subjective rights dalam pengelolaan lingkungan sebagaimana diatur dalam Pasal 28H dan adanya pengakuan elemen berwawasan lingkungan sebagaimana disebutkan dalam Pasal 33 ayat (4) UUD $1945 .{ }^{5}$

Namun demikian, UUD telah meletakkan landasan politik hukum pengelolaan lingkungan yang cukup kuat untuk menjadi acuan tertingi dalam pembentukan, pelaksanaan, dan penegakan hukum lingkungan. Oleh karenanya, sebagai politik hukum tertinggi, maka semua kebijakan hukum yang terkait dengan pengelolaan lingkungan, termasuk dalam konteks pelaksanaan otonomi daerah, harus merefleksikan nuansa hijau ini dalam produk hukumnya. Jika

${ }^{3}$ Jimly Asshiddiqie, Green Constitution: Nuansa Hijau Undang-Undang Dasar Negara Republik Indonesia Tahun 1945, Rajawali Pers, Jakarta, 2010, hlm. 91

${ }^{4}$ Jimly Asshiddiqie, Konstitusi Ekonomi, PT Kompas Media Nusantara, Jakarta, 2010, hlm. 282-283

5 Mas Ahmad Santosa, Greener Constitution: Solusi Strategis Pengarusutamaan Pembangunan Berkelanjutan Berwawasan Lingkungan, Makalah, Materi Amandemen UUD negara RI 1945, 2009, hlm. 9-10 
tidak, maka terbuka kemungkinan untuk dilakukan constitutional review ke Mahkamah Konstitusi. ${ }^{6}$

Peraturan lain yang menegaskan jaminan dan perlindungan bagi setiap orang untuk memperoleh lingkungan hidup yang sehat di Indonesia di atur dalam Pasal 9 ayat (3) Undang-Undang Nomor 39 Tahun 1999 tentang Hak Asasi Manusia yang menyebutkan bahwa hak untuk hidup sebagai salah satu hak asasi manusia diantaranya meliputi hak atas lingkungan hidup yang baik dan sehat. Ketentuan ini menunjukkan bahwa lingkungan hidup termasuk unsur yang penting dalam pemenuhan hak asasi manusia. Apabila terjadi pencemaran lingkungan yang mengakibatkan setiap orang tidak dapat menikmati lingkungan yang sehat, maka perbuatan tersebut dapat dikualifikasi sebagai pelanggaran atas hak untuk hidup.

Selama ini, kebijakan lingkungan hidup, meskipun sudah tertuang dalam bentuk undang-undang tetap tidak efektif karena kalah bersaing dengan kebijakankebijakan sektor atau bidang lain yang juga dituangkan dalam bentuk undangundang. Misalnya, UU tentang Lingkungan Hidup selalu dinomor-duakan apabila berbenturan dengan UU tentang Penanaman Modal, UU tentang Minyak dan Gas Bumi, UU tentang Kehutanan, UU tentang Pertambangan dan lain sebagainya.7

Selain UUD 1945 belum memberikan pengaturan yang maksimal tentang perlindungan atas lingkungan yang sehat di Indonesia, sumber masalah pengelolaan lingkungan lainnya berasal dari internal pemerintah seperti kegagalan kebijakan, kegagalan implementasi serta inefektivitas penataan kelembagaan. Menurut Santosa, hal tersebut dapat dilihat berikut ini: ${ }^{8}$

a. Aspek Kegagalan Kebijakan (Policy Failure)

Hal ini dapat diindikasikan dengan masih banyaknya kebijakan pembangunan yang tidak holistik, termasuk Undang-Undang Dasar 1945 yang tidak menyentuh aspek perlindungan daya dukung ekosistem dan fungsi lingkungan hidup; kebijakan tentang tenurial dan property rights yang tidak memberikan jaminan hak pada masyarakat adat; kebijakan yang sentralistis dan seragam; dan kebijakankebijakan yang tidak mendukung "pemerintah yang terbuka" atau open government.

b. Aspek Kegagalan Pelaksanaan (Implementation Failure)

Merupakan aspek yang paling krusial untuk segera dibenahi. Bagaimana menjadikan aparatur pemerintah kita, yang merupakan pelaksana kebijakan,

${ }^{6}$ Muhammad Akib, Politik. Hukum Lingkungan: Dinamika dan Refleksinya Dalam Produk Hukum Otonomi Daerah, PT RajaGrafindo Persada, Jakarta, 2012, hlm. 22

7 Jimly Asshiddiqie, Konstitusi Ekonomi, PT Kompas Media Nusantara, Jakarta, 2010, hlm. 280

8 Mas Ahmad Santosa, Good Governance Hukum Lingkungan, ICEL, Jakarta, 2001, hlm. 128-133 
menjadi profesional, memiliki integritas, dan responsif/aspiratif. Aparat pemerintah sebagai regulator pada umumnya menjalankan kepentingan yang bertentangan dengan kepentingan hajat hidup orang banyak (public interest). Pertentangan kepentingan ini disebabkan oleh pengaruh-pengaruh atau tekanan elite politik, kroni, atau kepentingan untuk memperkaya diri pribadi atau kelompoknya.

c. Aspek Penataan Kelembagaan yang Tidak Efektif (Institutional Failure)

Aspek kelembagaan meliputi kelembagaan di tingkat legislatif, eksekutif pusat dan daerah, dan juga kelembagaan di dalam masyarakat itu sendiri. Persoalan kelembagaan dalam pemerintahan bersumber dari bentuk dari kelembagaan itu sendiri (portofolio atau nonportofolio), keterbatasan mandat, cakupan kewenangan, dan lemahnya koordinasi. Cara pandang bahwa aspek lingkungan hidup merupakan urusan Komisi VIII DPR RI (Komisi yang membidangi lingkungan), dan bukan merupakan urusan komisi-komisi lainnya (misalnya yang menangani bidang kehutanan, perdagangan, dan industri) masih sangat kental. Tidaklah mengherankan apabila isu-isu tertentu yang menyebabkan kerusakan lingkungan hidup yang membawa dampak pada lingkungan hidup, kesehatan dan kehidupan masyarakat ditanggapi secara berbeda oleh komisi yang satu dengan yang lainnya.

\section{Kebijakan Hukum terhadap Tanggung Jawab TNCs atas Pelanggaran Hak Menikmati Lingkungan yang Sehat di Nigeria}

Nigeria telah mengkualifikasi hak untuk menikmati lingkungan hidup yang sehat sebagai hak asasi manusia sebagaimana bunyi Pasal atau section 20 dalam Konstitusi Nigeria (Constitution of the Federal Republic of Nigeria 1999); The State shall protect and improve the environment and safeguard the water, air and land, forest and wild life of Nigeria. Negara memiliki kewajiban untuk melindungi dan memperbaiki serta menjaga lingkungan yang meliputi air, udara, tanah, dan hutan di Nigeria supaya tetap terjaga dengan baik. Pasal 12 konstitusi Nigeria bahkan memuat ketentuan bahwa terkait dengan ratifikasi perjanjian internasional yang di dalamnya termasuk perjanjian mengenai lingkungan hidup oleh Majelis Nasional untuk menjadikannya sebagai hukum yang berlaku di Nigeria:

(1) No treaty between the Federation and any other country shall have the force of law to the extent to which any such treaty has been enacted into law by the National Assembly. (2) The National Assembly may make laws for the Federation or any part thereof with respect to matters not included in the he Exclusive Legislative List for the purpose of implementing a treaty. (3) A bill for an Act of the National Assembly passed pursuant to the provisions of subsection (2) of this section shall not be presented to the President for assent, and shall not be enacted unless it is ratified by a majority of all the House of Assembly in the Federation. 
Bahkan banyak yang menilai, keberadaan Pasal 20 Konstitusi Nigeria menjadi proteksi nyata guna terwujudnya lingkungan yang sehat bagi warga negaranya. Namun demikian, apabila dilihat dari sistematika bab-bab dalam Konstitusi Nigeria, hak atas lingkungan yang sehat tidak dimasukkan ke dalam Bab IV yang mengatur secara khusus hak dasar warga negaranya (fundamental right), tapi justru masuk ke dalam Bab II yang mengatur tentang tujuan dasar dan prinsip langsung kebijakan negara, sehingga ada yang menilai bahwa Konstitusi Nigeria tidak memuat ketentuan tentang hak atas lingkungan yang sehat secara langsung. Akan tetapi ketentuan tersebut justru telah mencerminkan tujuan fundamental dan prinsip kebijakan negara terhadap perlindungan lingkungan yang sehat. Dengan kata lain sesungguhnya Nigeria telah menyerap substansi hak atas lingkungan yang sehat dalam konstitusinya ${ }^{9}$, atau secara substansi Nigeria telah memiliki komitmen untuk menjamin warga negaranya merasakan lingkungan hidup yang sehat demi tercapainya pembangunan berkelanjutan. Komitmen tersebut kemudian dilegalisasikan ke dalam berbagai aturan organik yang berkaitan dengan perlindungan lingkungan hidup yang sehat diantaranya dapat dilihat pada tabel berikut.

Tabel 1

Laws And Regulations On The Environment In Nigeria

\begin{tabular}{|l|l|}
\hline No & \multicolumn{1}{|c|}{ Item } \\
\hline 1 & National Environmental Standards and Regulations Enforcement Agency \\
& (NESREA) Act \\
3 & Environmental Impact Assessment Act \\
4 & Harmful Waste (Special Criminal Provisions) Act \\
5 & Hydrocarbon Oil Refineries Act \\
6 & Nea Fisheries Act \\
7 & Pest Control of Production (special powers) Act \\
8 & Animal Diseases (control) Act \\
9 & Water Resources Act \\
10 & Nigerian Mining Corporation Act \\
11 & Environmental Pollution Control Law \\
\hline
\end{tabular}

${ }^{9}$ Hakeem Ijaiya, Environmental Rights in Nigeria and India, International Journal of Environmental and Development (IJED) Vol. 9 (2), hlm. 153-160 
Apabila dianalisis satu persatu pasal-pasal yang terkandung di dalam UU di atas, maka akan ditemukan pasal yang secara tegas menyebutkan bahwa perlindungan terhadap lingkungan hidup, khususnya lingkungan hidup yang sehat menjadi bagian yang tidak dipisahkan dari Nigeria. NESREA Act dan beberapa regulasi yang lain bahkan juga mengatur tentang adanya kewajiban bagi perusahaan untuk turut serta dalam melakukan perlindungan lingkungan hidup. Pengabaian atas kewajiban ini akan menyebabkan dijatuhkannya hukuman pidana bagi korporasi/perusahaan tersebut.

Regulasi yang mengatur Ketentuan Pidana Khusus Pembuangan Limbah Berbahaya atau Harmful Waste (Special Criminal Provisions) Act, melalui beberapa pasalnya menyebutkan bahwa seseorang atau korporasi tanpa ijin dari pihak yang berwenang dilarang membuang atau menyimpan limbah berbahaya yang bisa membayakan ekosistem, udara, tanah dan perairan di Nigeria. Aturan khusus pidana bagi yang melakukan tindakan kriminal berupa menyimpan ataupun membuang limbah berbahaya, jelas menjadi dasar konkrit bahwa Nigeria berusaha untuk melindungi lingkungan hidupnya supaya tetap lestari dan sehat, sehingga warga negaranya dapat menikmati keberadaannya. Ketentuan tersebut dapat dimaknai bahwa Pemerintah Nigeria berusaha mengambil tindakan yang diperlukan guna melindungi hak-hak rakyat supaya tidak dieksploitasi. ${ }^{10}$

Nigeria sebagai negara yang memiliki sumber minyak terbesar di Afrika, juga memiliki aturan yang melarang penyulingan minyak berjenis hidrokarbon dilakukan di tempat-tempat selain kilang minyak. Artinya Nigeria melarang penyulingan minyak dilakukan di sembarang tempat yang tidak diberikan lisensi oleh pemerintah. Larangan tersebut dimaksudkan supaya penyulingan minyak yang dilakukan oleh perusahaan dilakukan sesuai prosedur yang berlaku sehingga akan mudah cara mengontrolnya. Tujuannya supaya lingkungan di daerah tersebut terus terjaga kelestariannya, meskipun sebagian sumber daya alamnya diambil untuk kepentingan ekonomi.

Peraturan yang berkaitan dengan hal di atas adalah Hydrocarbon Oil Refineries Act, CAP H5, LFN 2004. Pasal 1 UU tersebut menyebutkan bahwa pemerintah melarang setiap penyulingan minyak berlisensi hidrokarbon di tempat-tempat selain 
kilang (Hydrocarbon Oil Refineries Act). Kemudian di Pasal 9 memberi penegasan bahwa keberadaan kilang sebagai fasilitas yang digunakan melakukan penyulingan minyak dimaksudkan untuk mencegah terjadinya polusi.

Berbagai regulasi yang memproteksi lingkungan hidup di Nigeria, secara umum bisa diartikan bahwa meskipun di dalam konstitusinya tidak memasukkan hak atas lingkungan hidup ke dalam bagian hak dasar warga negaranya (fundamental rights). Namun banyaknya aturan organik yang secara substansi memberikan jaminan kepada setiap orang untuk melindungi dan menikmati lingkungan hidup yang sehat, maka Nigeria menjadi salah satu negara yang cukup peduli terhadap lingkungan hidupnya supaya tetap murni dan bisa dinikmati secara sehat oleh warga negaranya.

\section{Kebijakan Hukum terhadap Tanggung Jawab TNCs atas Pelanggaran Hak Menikmati Lingkungan yang Sehat di Ekuador}

Pelanggaran terhadap hak menikmati lingkungan hidup yang sehat di Ekuador secara signifikan telah menimbulkan dampak yang sangat serius terhadap kesehatan, sehingga mempengaruhi juga hak untuk hidup sebagai hak yang fundemental. ${ }^{11}$ Salah satu kasus pelanggaran hak menikmati lingkungan hidup yang sehat yaitu kasus Aguinda Et Al. V. Chevron Corporation, ${ }^{12}$ yang melibatkan masyarakat adat Lago Agrio melawan Chevron Corporation, dimana penggugat mengklaim bahwa tergugat dalam kegiatan operasinya telah melakukan pembuangan limbah dan air sisa produksi minyak secara langsung ke lingkungan di mana hal tersebut tidak sesuai dengan prosedur yang berlaku di Ekuador. Akibatnya, lebih 2.5 juta hektar hutan rusak dan pembuangan air sisa produksi ke sungai telah mencemari perairan, yang saat ini telah terkontaminasi dengan bahan kimia dan logam berat seperti benzena, toluena, arsenik, timbal, merkuri, dan kadmium. Hal ini dikuatkan dengan penelitian yang dilakukan oleh Pemerintah Ekuador pada tahun 1987 yang menemukan bahwa minyak mentah telah secara teratur dibuang ke hutan, lahan pertanian dan perairan serta di $80 \%$

\footnotetext{
${ }^{11}$ Center for Economic and Social rights, 1999, http://www.cesr.org/downloads/ Recognizing\%20the\%20Right\%20to\%20Health\%20in\%20Ecuador.pdf. Diakses 12 September 2014.

12 Peggy Rodgers Kalas, "The Implications of Jota V. Texaco and the Accountability of Transnational Corporations", Vol. 12. Pace Int'l L. Rev.(2000), hlm.49.
} 
tempat pembuangan sampah yang dibuat seadanya sehingga hal ini menyebabkan berbagai masalah kesehatan bagi masyarakat adat di Lago Agrio. ${ }^{13}$

Sejarah kelam pelanggaran hak menikmati lingkungan hidup yang sehat sebagaimana dijelaskan dalam kasus Aguinda Et Al. V. Chevron Corporation, ${ }^{14}$ telah merubah secara signifikan kebijakan lingkungan di Ekuador. Pasal 83 Konstitusi Ekuador telah mengakui hak untuk menikmati lingkungan hidup yang sehat sebagai hak konstitusi: "Ecuadorians have the following duties and obligations, without detriment to others provided for by the Constitution or by law:.. (6) To respect the rights of nature, preserve a healthy environment and use natural resources rationally, sustainably and durably".

Pemerintah Ekuador juga telah mengatur tentang partisipasi publik dalam perlindungan lingkungan yang diatur dalam Pasal 57:

"Indigenous communities, peoples and nations are recognized and guaranteed, in conformity with the Constitution and human rights agreements, conventions, declarations and other international instruments, the following collective rights: (6) To participate in the use, administration and conservation of natural renewable resources located on their lands. (7) To free prior informed consultation, within a reasonable period of time, on the plans and programs for prospecting, producing and marketing nonrenewable resources located on their lands and which could have an environmental or cultural impact on them; to participate in the profits earned from these projects and to receive compensation for social, cultural and environmental damages caused to them. The consultation that must be conducted by the competent authorities shall be mandatory and in due time. If consent of the consulted community is not obtained, steps provided for by the Constitution and the law shall be taken...."

Pasal tersebut telah mengakui adanya hak masyarakat adat untuk menikmati lingkungan yang sehat, hak untuk menggunakan sumber daya alam, hak untuk dimintai pendapatnya tentang pemanfaatan sumber alam di masyarakat adat. ${ }^{15}$ Selain itu, pengaturan hak untuk menikmati lingkungan hidup yang sehat juga diatur dalam Ecuadorian Mining Law. Pasal 34 UU ini mengatur

${ }^{13}$ Ibid.

14 Maura Mullen de Bolívar, "A Comparison of Protecting the Environmental Interests of LatinAmerican Indigenous Communities from Transnational Corporations Under International Human Rights and Environmental Law" J. Transnat'l L. \& Pol'y, (Fall, 1998), hlm. 108-109.

15 Upasana Khatri, "Indigenous Peoples' Right to Free, Prior, and Informed Consent in the Context of StateSponsored Development: The New Standard Set by Sarayaku V; Ecuador and its Potential to Delegitimize the Belo Monte Dam Upasana Khatri American University Washington College of Law." http://digitalcommons.wcl.american.edu/cgi/viewcontent.cgi?article=1805\&context=auilr. Diakses 22 Mei 2015. 
tentang pembayaran konservasi paten untuk setiap hektar lokasi pertambangan setiap tahun yang dilaksanakan tiap bulan Maret:

"Mining concessionaires shall pay an annual conservation patent fee for each mining hectare by March in each year, which fee shall correspond to the current calendar year up to the payment date, in accordance with the scale set out in the following paragraph. In no case shall the payment date be extended, either by administrative or judicial means".

Kewajiban pembayaran patent fee konservasi ${ }^{16}$ untuk setiap hektar lokasi pertambangan merupakan suatu perwujudan partisipasi pelaku usaha dalam konservasi. Pelaku usaha pertambangan juga memiliki kewajiban untuk membayar ganti rugi sebagai perwujutan dari prinsip polluter pay principle sebagaimana yang diatur dalam Pasal 70:

"Mining concession holders are required to carry out their works using methods and techniques that minimize damage to soil, the environment, natural or cultural heritage, adjacent concessions, third parties and, in any event, must compensate any damage or harm they may have caused during the course of their works. Failure to observe the methods and techniques referred to in the preceding paragraph shall be considered as grounds for the suspension of mining activities, in addition to the corresponding penalties".

Peraturan ini menjadi landasan hukum pemerintah untuk menghentikan aktivitas pertambangan dan juga pembayaran ganti kerugian, kalau pemegang konsesi menimbulkan kerugian atau kerusakan lingkungan selama melakukan kegiatannya. Kewajiban untuk melakukan pencegahan dan pencemaran lingkungan yang disebabkan oleh kegiatan pertambangan diantisipasi dengan adanya kewajiban pembuatan analisis mengenai dampak lingkungan (AMDAL) dan audit lingkungan sebagaimana diatur pada Pasal 78:

"Holders of mining concessions and beneficiation, smelting and refinery plants shall, prior to the commencement of mining activities in any phase, in accordance with the provisions of the following article, prepare and submit environmental impact studies in the initial exploration phase and definitive environmental impact studies and environmental management plans in the advanced exploration phase and subsequent phases, in order to prevent, mitigate, control and rehabilitate environmental and social impacts arising out of their activities. Such studies must be approved by the Ministry of the Environment, with the grant of the respective Environmental License".

16 UNEP, "Analysis of formalization approaches in the artisanal and small-scale gold mining sector based on experiences in Ecuador, Mongolia, Peru, Tanzania and Uganda A compendium of case studies". http://www.unep.org/chemicalsandwaste/Portals/9/Mercury/Documents/ASGM/Formalization ARM/Case \%20Studies\%20Compendium\%20June\%202012.pdf. Diakses pada tanggal 26 Mei 2015. 
Kewajiban pembuatan analisis lingkungan (ANDAL) dan juga pembuatan AMDAL harus dilakukan sebelum kegiatan pertambangan di mulai. ${ }^{17} \mathrm{Hal}$ ini untuk melakukan penanggulangan dan rehabilitasi terhadap lingkungan dan mencegah terjadinya dampak sosial terhadap masyarakat disekitar kegiatan pertambangan. Studi atau analisis tersebut harus memperoleh persetujuan dari Menteri Lingkungan Hidup. Adapun beberapa prinsip perlindungan dan pengelolaan lingkungan diatur dalam Pasal 395 Konstitusi Ekuador:

The Constitution recognizes the following environmental principles: (1) The State shall guarantee a sustainable model of development, one that is environmentally balanced and respectful of cultural diversity, conserves biodiversity and the natural regeneration capacity of ecosystems, and ensures meeting the needs of present and future generations. (2) Environmentalmanagement policies shall be applied cutting across all sectors and dimensions and shall be mandatorily enforced by the State at all of its levels and by all natural persons or legal entities in the country's territory. (3) The State shall guarantee the active and permanent participation of affected persons, communities, peoples and nations in the planning, implementation and monitoring of all activities exerting environmental impacts. (4) In the event of doubt about the scope of legal provisions for environmental issues, it is the most favorable interpretation of their effective force for the protection of nature that shall prevail.

Konstitusi Ekuador juga memberikan kesempatan adanya partisipasi publik terhadap semua keputusan pemerintah yang dapat mempengaruhi lingkungan masyarakat. Partisipasi masyarakat (public participation) merupakan hal penting yang dijamin oleh Konsitusi. Segala keputusan yang berdampak pada lingkungan, masyarakat dilibatkan untuk dimintai kesepakatannya. ${ }^{18}$ Pasal 389 menyatakan:

"All state decision or authorization that could affect the environment shall be consulted with the community, which shall be informed fully and on a timely basis. The consulting subject shall be the State. The law shall regulate prior consultation, public participation, time-limits, the subject consulted and the appraisal and objection criteria used with regard to the activity that is being submitted to consultation. The State shall take into consideration the opinion of the community on the basis of the criteria provided for by law and international human rights instruments. If the above-mentioned consultation process leads to majority opposition by the respective community, the decision whether to implement or not the project shall be adopted by a resolution that is duly substantiated by the corresponding higher administrative body in accordance with the law".

17 Workabeba Belkele Woldemelekot, "Liability of Transnational Corporations for Indegenous Peoples Human Rights Violation”, Master Thesis, www.fao.org/3/a-i0970e/i0970e01e.pdf. hlm, 412-413.

18 Thomas C. Beierle, "Public Participation in Environmental Decisions: An Evaluation Framework Using Social Goals”. http://www.rff.org/files/sharepoint/WorkImages/Download/RFF-DP-99-06.pdf. Diakses Tanggal 24 Mei 2015. 
Menurut Konstitusi Equador, sumber daya alam merupakan milik negara yang tidak dapat diganggu gugat. Pasal 1 menyatakan: “... Nonrenewable natural resources of the State's territory belong to its inalienable and absolute assets, which are not subject to a statute of limitations. Sedangkan berkaitan dengan kewenangan terhadap pemanfaatan sumber alam berada di pemerintah pusat diatur dalam Pasal 261: The central State shall have exclusive jurisdiction over: (7) Protected natural areas and natural resources. 39 (11) Energy resources; minerals, oil and gas, and water resources, biodiversity and forest resources".

\section{Kebijakan Hukum Atas Hak Menikmati Lingkungan Hidup yang Sehat di India}

Konstitusi India tidak ada satu pasal pun yang secara eksplisit menyebutkan bahwa hak menikmati lingkungan hidup yang sehat merupakan bagian dari HAM/ hak fundamental. ${ }^{19}$ Namun dalam perkembangannya, berdasarkan interpretasi Mahkamah Agung terkait dengan hak untuk tinggal di lingkungan yang sehat dan layak serta terbebas dari penyakit dan infeksi dinyatakan sebagai bagian dari hak fundamental sebagaimana di sebutkan dalam Pasal 21 Konstitusi India. ${ }^{20} \mathrm{Hal}$ ini didasarkan atas putusan Mahkamah Agung India pada kasus Maneka Gandhi vs. Union of India, AIR 1978 SC 597 dan M.C. Mehta vs. Union of India, AIR 1987 SC 1086 (Oleum Gas Leak Case)21 serta putusan pengadilan tinggi pada kasus Bhopal. ${ }^{22}$

India sebagai salah satu negara berkembang memiliki pengalaman yang buruk dalam perlindungan lingkungan. Kasus Bhopal merupakan salah satu kasus yang merenggut banyak jiwa dan menyebabkan pencemaran lingkungan yang serius. Kasus lingkungan yang disebabkan oleh kegiatan industri lainnya adalah kasus Oleam Gas Leak. Baik dalam kasus Bhopal 23 dan kasus Oleam Gas Leak, the Supreme Court of India telah memberikan putusan yang berpihak

${ }^{19}$ India Constitution, http://www.cgsird.gov.in/constitution.pdf. Diakses 14 September 2014.

${ }^{20}$ Ibid.

${ }^{21}$ K.G. Balakrishnan, "Judicial Activism under the Indian Constitution", http://supremecourtofindia.nic.in / speeches/speeches 2009/judicial activism tcd dublin 14-10-09.pdf. Diakses tanggal 12 September 2014.

22 Sukanya Pillay, "Absence of Justice: Lessons from The Bhopal Union Carbide Disaster for Latin America”, Vol. 14, Mich. St. J. Int'l L, (2006), hlm. 482-483.

${ }^{23}$ Sudhir K. Chopra, "Multinational Corporations in the Aftermath of Bhopal: The Need for a New Comprehensive Global Regime for Transnational Corporate Activity", Vol. 29, Val. U. L. Rev., (Fall, 1994), hlm. 238-239. Lihat juga, Sanjib Dutta, "The Bhopal Gas Tragedy", http://www.econ.upf.edu/ lemenestrel LIMG/pdf/bhopal gas tragedy dutta.pdf, Dialses tanggal 13 September, 2015. 
kepada kepentingan publik, dengan memberikan sanksi kepada perusahaan yang telah menyebabkan pencemaran tersebut dengan membayar kompensasi.

Berbagai kasus pencemaran lingkungan yang terjadi di India, bukan berarti pemerintah India tidak mengatur hak untuk menikmati lingkungan yang sehat bagi warganegaranya. Berdasarkan putusan Mahkamah Agung India pada kasus Maneka Gandhi vs. Union of India, AIR 1978 SC 597 dan M.C. Mehta vs. Union of India, AIR 1987 SC 1086 (Oleum Gas Leak Case) serta putusan pengadilan tinggi pada kasus T. Damodar Rao vs. S.O. ${ }^{24}$ Municipal Corporation, Hyderabad, AIR 1987 A.P. 171, Pemerintah India mewajibkan perusahaan yang melakukan aktivitas/kegiatan di India untuk berpartisipasi dalam perlindungan lingkungan, yang diatur dalam berbagai ketentuan perundang-undangan.

Konstitusi India Pasal 51A menyatakan bahwa setiap warga negara memiliki kewajiban untuk melindungi dan memperbaiki lingkungan yang di dalamnya termasuk hutan, danau, sungai dan kehidupan liar. Adapun pengertian warga negara tidak terbatas hanya pada individu saja namun juga termasuk perusahaan baik itu berbadan hukum maupun tidak, sebagaimana di jelaskan dalam Pasal 16 The Environment Protection Act, $1986^{25}$ bahwa India memberikan pengaturan khusus tentang tindak pidana yang di lakukan oleh perusahaan terkait dengan pelanggaran atas ketentuan dari undang-undang ini.

Ketentuan perlindungan lingkungan juga dicantumkan dalam Pasal 166 (2) The Company Act 2013, ${ }^{26}$ terkait dengan kewajiban direktur untuk mendasari setiap perbuatannya pada itikat baik (good faith) untuk mencapai tujuan perusahaan demi tercapainya kepentingan anggota, perusahaan, pekerja, pemegang saham, masyarakat dan perlindungan lingkungan. Pasal ini menyatakan bahwa setiap tindakan yang dilakukan oleh direktur perusahaan tidak hanya berlandaskan keuntungan semata tapi haruslah mengakomodasi perlindungan lingkungan. Pasal 135 The Company Act 2013, terkait dengan Corporate Social Responsibility (CSR) menyatakan bahwa perusahaan memiliki

24 Brind Kumar, et. all, "Brief Review of the Legislative Aspects of Noise Pollution. "http://home.uchicago.edu/ mstaisch/Sharad/papers/Legislative $\% 20$ Aspects $\% 20$ of $\% 20$ Noise $\% 20$ Pollution.p df, Diakses tanggal 5 Oktober 2014, hlm. 6.

25 The Environment Protection Act 1986, http://envfor.nic.in/legis/env/eprotect act 1986.pdf. Diakses tanggal 26 September, 2014.

26 Indian Company Act, http://www.mca.gov.in/Ministry/pdf/CompaniesAct2013.pdf. Diakses Tanggal 5 Oktober 2014. 
kewajiban untuk mengalokasikan dana dengan jumlah tertentu untuk tujuan penjaminan kelestarian lingkungan. Berdasarkan ketentuan-ketentuan tersebut dapat disimpulkan bahwa perlindungan lingkungan telah menjadi kewajiban dari setiap perusahaan-perusahaan yang melakukan kegiatan usaha di India.

Adapun berkaitan dengan kewajiban negara dalam perlindungan lingkungan dimuat dalam Konstitusi India antara lain dalam Pasal 48A: "The State shall endeavour to protect and improve the environment and to safeguard the forests and wild life of the country". Sedangkan Pasal 51A menyatakan: "It shall be the duty of every citizen of India to protect and improve the natural environment including forests, lakes, rivers and wild life, and to have compassion for living creatures. Berdasarkan kedua pasal tersebut dapat disimpulkan bahwa negara bertanggung jawab atas perlindungan dan perbaikan lingkungan hidup, namun juga membebankan kewajiban kepada setiap warga negara untuk melindungi dan memperbaiki lingkungan. Hal ini menunjukkan bahwa setiap perlindungan dan perbaikan lingkungan menjadi tanggung jawab bersama antara negara dan warganya.

Selain itu, India memiliki National Green Tribunal Act 2010.27 UndangUndang ini merupakan undang-undang pembentukan pengadilan khusus terkait dengan perlindungan lingkungan hidup. Green Tribunal memiliki jurisdiksi atas segala kasus perdata tentang persengketaan terkait dengan lingkungan hidup, termasuk penegakan legal rights ${ }^{28}$ yang berhubungan dengan lingkungan hidup.

Beberapa peraturan yang dipaparkan di atas menunjukkan bahwa India memiliki kebijakan perlindungan lingkungan yang cukup baik. Selain itu aturan tersebut memperlihatkan bagaimana pentingnya sinergitas antara pemerintah dan masyarakat dalam perlindungan lingkungan, dan pemberian kewajiban bagi perusahan untuk bertanggung jawab atas kelestarian lingkungan. Hal yang cukup penting adalah pembentukan pengadilan khusus lingkungan sebagai salah satu bukti keseriusan India dalam melaksanakan perlindungan lingkungan serta penjaminan hak-hak terkait dengan lingkungan hidup.

${ }^{27}$ National Green Tribunal Act 2010, http://faolex.fao.org/docs/pdf/ind98219.pdf, diakses 8 Oltober

${ }^{28}$ Swapan kumar Patra and V.V. Khrisna, "National Green Tribunal and Environmental Justice in India", http://www.niscair.res.in/jinfo/ijms/ijms-forthcoming-articles/IJMS-PR-April $\% 202015 / \mathrm{MS} \% 202615 \%$ 20Edited.pdf. Diakses tanggal 26 desember, 2014. 
Kebijakan Hukum Atas Hak Menikmati Lingkungan Hidup yang Sehat di Finlandia

Finlandia sebagai salah satu negara di Eropa memiliki kebijakan hukum tentang perlindungan lingkungan yang lebih komprehensif dibandingkan dengan kebijakan hukum di negara berkembang. Finlandia sebagai negara maju, walaupun memiliki kasus lingkungan yang disebabkan olen TNCs namun dampaknya tidak seserius di empat negara tersebut. Hal ini disebabkan oleh berbagai faktor, antara lain kesadaran masyarakat akan hak untuk menikmati lingkungan hidup yang sehat sebagai bagian dari hak asasi manusia dan juga kehendak politik (political will) dari pemerintah Finlandia yang cukup baik.

Namun demikian bukan berarti di Finlandia tidak ada kasus tentang pencemaran lingkungan. Salah satu kasus pencemaran lingkungan yang terjadi adalah kasus Talvivaara Mining Company. Dalam kasus ini pemerintah Finlandia telah bertindak tegas untuk memberikan sanksi yang diselaraskan dengan ketentuan perlindungan lingkungan di Uni Eropa. ${ }^{29}$ Kebijakan dan ketentuan perlindungan lingkungan di Finlandia terintegrasi dalam Konstitusi dan berbagai peraturan sebagai berikut: The Constitution of Finland, the Environment Protection Act, ${ }^{30}$ Mining Act, dan Juga Limited Liability Company Act.

Pasal 20 Konstitusi Finlandia berisi komitmen pemerintah dalam pelestarian lingkungan dan kewajiban perusahaan untuk melakukan perlindungan Lingkungan:

"The public authorities shall endeavour to guarantee for everyone the right to a healthy environment and for everyone the possibility to influence the decisions that concern their own living environment. Responsibility for the environment Nature and its biodiversity, the environment and the national heritage are the responsibility of everyone".

Selain dimuat dalam konstitusinya, Finlandia juga memiliki UU lingkungan yang secara khusus mengatur perlindungan lingkungan. Pasal 5 Environmental Protection Act menyatakan:

${ }^{29}$ Dalam Putusannya menyatakan: "Talvivaara telah melakukan pelanggaran berat terhadap lingkungan. Pemerintah melalui institusi terkait mewajibkan Talvivaara untuk membayar ganti rugi atas kerusakan lingkungan yang mereka lakukan, hal ini di dasarkan atas asas 'polluter pay principle yang di adopsi dalam Environmental Protection Act Finlandia". Tihinen Taimo, Significant Mining Incident in Finland", http://www.hsa.ie/eng/Your Industry/Mining/Head of State Mining Authorities Meetings/PDF-TihinenTaimo-SIGNIFICANT-MINING-INCIDENTS-IN-FINLAND. Diakses Tanggal 23 Pebruari 2015.

30 Finland Environmental Act, 2000. https://www.finlex.fi/en/laki/kaannokset/2000/en20000086. pdf. Dakses tanggal 28 Desember 2014. 
(1) Operators must have sufficient knowledge of their activities' environmental impact and risks and of ways to reduce harmful effects (knowledge requirement).

(2) If the activities cause or may directly result in environmental pollution, the operator must take the appropriate action without delay in order to prevent pollution, or, if pollution has already resulted, to reduce it to a minimum (obligation to prevent pollution). (385/2009)

Yang dimaksud operator pada undang-undang ini adalah individu dan badan hukum. (Protection Act, Section 3). Operator harus memiliki pengetahuan yang memadai tentang dampak lingkungan yang disebabkan oleh aktivitasnya, dan juga mengetahui tentang kemungkinan risiko yang dihadapinya dan tahu bagaimana caranya untuk mengurangi dampak yang berbahaya. Jika aktivitas tersebut menyebabkan pencemaran maka harus sesegera mungkin melakukan suatu tindakan untuk mencegah terjadinya polusi, atau kalau polusi sudah terjadi, maka sedapat mungkin untuk mengurangi dampak yang membahayakan terhadap lingkungan maupun kesehatan manusia.

Dalam hal perijinan pertambangan, pemegang ijin pertambangan (mining permit holder) mengacu kepada natural person dan legal person. Pasal 31 ayat (1) dan (2) Finlandia Mining Act. menyatakan:

Parties eligible to apply for an exploration permit, mining permit, or gold panning permit are: 1) a natural person of age who is not declared bankrupt and whose competency has not been restricted under the Guardianship Services Act (442/1999); 2) a legal person. Moreover, subject to the conditions laid down in this Act, a Government institution may apply for an exploration permit.

Berdasarkan Finlandia Mining Act, Pasal 18(1): The mining permit holder is obliged to ensure that: 1) mining activities do not cause damage to people's health or danger to public safety. Ketentuan ini memberikan suatu kewajiban bahwa pemegang ijin pertambangan dalam melaksanakan usahanya tidak menyebabkan kerusakan lingkungan dan membahayakan kesehatan manusia.

Kebijakan lingkungan secara umum di Finlandia sudah cukup baik dan melibatkan partisipasi masyarakat dalam pengambilan keputusan yang memiliki dampak terhadap lingkungan. ${ }^{31}$ Selain itu, Pasal 37 (3) Charter of Fundamental Rights of the European Union menegaskan: A high level of environmental protection and

31 Ritva Jolkkonen, "Public involvement in environmental issues in the ASEM - background and Overview", https://bch.cbd.int/protocol/outreach/ASEM.pd. Diakses pada Tanggal 6 Mei 2015. 
the improvement of the quality of the environment must be integrated into the policies of the Union and ensured in accordance with the principle of sustainable development. Charter ini memberikan kewajiban kepada negara anggota Uni Eropa untuk mengintegrasikan perlindungan lingkungan dan peningkatan kualitas lingkungan dalam kebijakan lingkungan Uni Eropa untuk menjamin bahwa kebijakan tersebut sesuai dengan prinsip pembangunan berkelanjutan.

Di level nasional lembaga/institusi yang bertanggung jawab dalam pemberian ijin pertambangan memiliki kewenangan yang cukup penting sebagaimana yang ditur pada Pasal 5 Mining Act: The Finnish Safety and Chemicals Agency acts as the mining authority referred to in this Act. Pasal 33 Mining Act menyatakan:

Licensing Authorities: The Government shall decide on matters concerning a redemption permit for a mining area and on mining permits related to the production of uranium or thorium. The mining authority shall make decisions concerning reservation notifications, exploration permits, and gold panning permits, as well as matters other than those concerning mining permits referred to in subsection 1.

Ketentuan ini berkaitan dengan lisensi menjadi kewenangan pemerintah untuk memutuskan masalah ijin pembuangan limbah di lokasi pertambangan dan ijin untuk pemproduksi uranium atau thorium. Selian itu institusi ini juga harus memutuskan ijin untuk melakukan eksplorasi. Khusus untuk sektor pertambangan, pengaturan khususnya mengacu pada Finlandia Mining Act. Terkait perlindungan lingkungan pengaturan dalam undang-undang ini mengacu pada banyak pasal, beberapa diantaranya:

(a) General principles pada pasal 6 ayat (1), (2), (3), (4) dan (5). (b) Kompensasi jika terjadi -environmental damage" Pada Pasal 105 menyatakan: As concerns damage or inconvenience caused by pollution of water, air, or soil, or by noise, vibration, radiation, light, heat, smell, or similar nuisance, the provisions laid down in section 12 of the Act on Compensation for Environmental Damage 32(737/1994) shall apply. (c) Rencana internal penyelamatan dalam kegiatan pertambangan (the internal rescue plan for a mine) dalam pasal 115 menyatakan: "For the purpose of mining operations, the mining operator shall prepare an internal rescue plan for the mine. The internal rescue plan for a mine shall specify the following: 8) preparation for repairing the damage caused by accidents, and clearing the environment."

32 Pasal 105 Finland Mining Act, https://www.finlex.fi/en/laki/kaannokset/2011/en20110621.pdf. Diakses pada tanggal 12 Januari 2015. 
Berdasarkan penelitian yang telah dilakukan, Finlandia telah mengintegrasikan kebijakan lingkungan dalam bebagai peraturan perundangundangan yang saling sinergi satu dan lainnya. Namun demikian kebijakan berkaitan dengan hak untuk menikmati lingkungan hidup yang sehat sebagai hak konstitusi dan hak asasi manusia memang tidak secara eksplisit dicantumkan dalam setiap perundang-undangan yang berkaitan dengan eksploitasi sumber daya alam ataupun pertambangan. Beberapa perundang-undangan Finlandia yang telah mengintegrasikan perlindungan lingkungan, antara lain the Constitution of Finland 11 June 1999 (731/1999, amendments up to 1112 / 2011 included), Environmental Protection Act (86/2000; amendments up to 728/2011 included), Mining Act (621/2011), Charter of Fundamental Rights of the European Union 2000/C 364/01, Act on Investment Firms 26.7.1996/579, Act on the Right of a Foreign Investment Firm to Provide Investment Services in Finland 26.7.1996/580.

\section{Persamaan dan Perbedaan Kebijakan terhadap Tanggung Jawab TNCs dalam Perlindungan Hak Menikmati Lingkungan yang Sehat}

Pola kebijakan hukum terhadap tanggung jawab TNCs atas pelanggaran hak untuk menikmati lingkungan yang sehat di empat negara berkembang yaitu Indonesia, India, Nigeria, Ekuador dan satu negara maju yaitu Finlandia ditemukan beberapa berbedaan dan persamaan.

Titik persamaan di antaranya, pertama, adanya penjaminan hak untuk memperoleh lingkungan hidup yang baik dan sehat dalam konstitusi. Meskipun terdapat negara yang tidak memasukkan secara eksplisit bahwa hak memperoleh lingkungan yang baik dan sehat ke dalam hak dasar warga negaranya yaitu negara Nigeria dan India, akan tetapi Nigeria memasukkannya ke dalam Bab II yang mengatur tentang tujuan dasar dan prinsip langsung kebijakan negara. Sedangkan di India, dalam perkembangannya Putusan Mahkamah Agung India melalui interpretasinya menyatakan bahwa hak untuk tinggal di lingkungan yang sehat dan layak serta terbebas dari penyakit dan infeksi dinyatakan sebagai bagian dari hak fundamental sebagaimana di sebutkan dalam Pasal 21 Konstitusi India. Dengan demikian kelima negara (Indonesia, Nigeria, Ekuador, India, dan Finlandia) sama- 
sama telah mengakui hak untuk memperoleh lingkungan yang baik dan sehat sebagai hak fundamental yang diatur dalam konstitusi bagi warga negaranya.

Kedua, dalam upaya pencegahan terjadinya masalah lingkungan dengan diterapkannya AMDAL ${ }^{33}$ sebelum dilakukannya kegiatan/usaha yang berkemungkinan menimbulkan dampak negatif terhadap lingkungan hidup. Penerapan AMDAL ini juga merupakan bentuk pengintegrasian perlindungan lingkungan dengan pembangunan.

Ketiga, pada tataran kebijakan pertanggungjawaban atas perusakan atau pencemaran lingkungan. Kelima negara menerapkan prinsip polluter pay principle, yaitu beban tanggung jawab atas timbulnya masalah lingkungan diletakkan pada pihak yang karena aktivitasnya menyebabkan timbulnya masalah lingkungan. Polluter pay principle 34 merupakan salah satu prinsip yang memang telah diadopsi oleh seluruh negara di dunia. Adanya prinsip ini juga melahirkan kebijakan di setiap negara bahwa perlindungan lingkungan dan tindakan pencegahan dari perusakan ataupun pencemaran merupakan tanggung jawab setiap orang, baik sebagai individu maupun sebagai institusi, lembaga, dan organisasi.

Adapun perbedaannya adalah: Pertama, dalam peraturan di bawah Konstitusi memang terjadi perbedaan pengaturan berkaitan dengan hak untuk menikmati lingkungan sehat. Berkaitan dengan masalah limbah berbahaya dan beracun (B3) yang merupakan limbah industri, tentua saja pengaturannya tidaklah persis sama. ${ }^{35}$ Masing-masing negara memiliki standar yang memadai sesuai dengan peraturan yang berlaku di negara yang bersangkutan demikian juga tentang instansi yang bertanggung jawab atau yang memiliki otoritas penanganan limbah B3.

Kedua, hak masyarakat adat untuk menikmati lingkungan yang sehat, hak untuk menggunakan sumber daya alam, hak untuk dimintai pendapatnya tentang pemanfaatan sumber alam yang terletak di wilayah yang dihuni oleh

${ }^{33}$ Karlheinz Spitz and Yahya Husin “, The AMDAL Process and the Equator Principles Common themes and apparent differences”, PUBLIC\%20PARTICIPATION\%202/AMDAL\%20PAPER.pdf. Diakses tanggal 16 April 2015.

34 Michael Faure and Nicole Niessen, " Environmental Law and Development Lessons from the Indonesian Experience. http://www.untag-smd.ac.id/files/Perpustakaan Digital 1/ENVIRONMENTAL \%20LAW-INDONESIA \%20Environmental $\% 201$ law $\% 20$ in $\% 20$ development $\% 20 \% 201$ e. Diakses tanggal 4 Maret 2015.

35 UNDP, “Assessment of Development Results Indonesia Evaluation of UNDP Contribution”, http://www.oecd.org/derec/undp/47865010.pdf, Diakses tanggal 12 Pebruari 2015. 
masyarakat hukum adat, hak untuk mengembangkan dan melindungi pengetahuan masyarakat hukum adat. Istilah masyarakat adat dalam Konstitusi Indonesia lebih dikenal dengan istilah masyarakat hukum adat. Kebijakan Indonesia terhadap masyarakat hukum adat telah diatur dalam UUD NRI Tahun 1945 Pasal 18B ayat (2). Sedangkan hak masyarakat hukum adat ini tidak semua Konstitusi mencantumkannya seperti, misalnya India.

Ketiga, adanya kewajiban pembayaran patent fee konservasi yang daitur dalam UU Ekuador untuk setiap hektar lokasi pertambangan dan kewajiban bagi pemegang konsesi kegiatan pertambangan untuk melakukan pengembalian fungsi lingkungan/recovery. Ketentuan ini memang tidak sama persis yang diatur di Indonesia. Kalau di Indonesia dalam Undang-Undang Nomor 4 tahun 2009 tentang Pertambangan Mineral dan Batubara mewajibkan pada setiap pihak yang melakukan kegiatan pertambangan untuk melakukan Reklamasi 36 dan Kegiatan Pasca tambang 37 .

Keempat, Pembentukan pengadilan khusus terkait dengan perlindungan lingkungan hidup. Dari kelima negara yang diteliti, India merupakan negara satu-satunya yang memiliki pengadilan khusus ${ }^{38}$ untuk menangani kasus-kasus lingkungan hidup. Sementara 4 negara lainnya diselesaikan melalui pengadilan umum.

\section{Penutup}

Berdasarkan hasil penelitian dan pembahasan yang telah dilakukan terhadap tanggung jawab TNCs yang telah melanggar hak untuk menikmati lingkungan yang sehat di Indonesia, Nigeria, Ekuador, India dan Finlandia, maka dapat disimpulkan bahwa kebijakan hukum lima negara tersebut terdapat persamaan dan perbedaan sebagai berikut:

\footnotetext{
${ }^{36}$ Reklamasi adalah kegiatan yang dilakukan sepanjang tahapan usaha pertambangan untuk menata, memulihkan, dan memperbaiki kualitas lingkungan dan ekosistem agar dapat berfungsi kembali sesuai peruntukannya. (Pasal 1 angka 26 UU Nomor 4 Tahun 2009).

${ }^{37}$ Kegiatan terencana, sistematis, dan berlanjut setelah akhir sebagian atau seluruh kegiatan usaha pertambangan untuk memulihkan fungsi lingkungan alam dan fungsi sosial menurut kondisi lokal di seluruh wilayah pertambangan. (Pasal 1 angka 27 UU Nomor 4 Tahun 2009).

38 Bharat H. Desai and Balraj Sidhu, "On the Quest for Green Courts in India", law.pace.edu/sites/default/files/IJIEA/jciDesai_India_3-17_cropped.pdf. Diakses tanggal 16 Maret 2015.
} 
Pertama, negara berkembang mengalami latar belakang yang sama yaitu adanya pelanggaran hak untuk menikmati lingkungan hidup yang sehat yang telah dilanggar oleh TNCs. Negara-negara ini kemudian memperbaiki diri dengan mengeluarkan berbagai kebijakan lingkungan dan membuat berbagai macam undang-undang untuk melindungi hak tersebut. Berdasarkan empat negara yang berkembang dan satu negara maju yang sudah diteliti, semuanya telah mengakui hak menikmati lingkungan hidup yang sehat sebagai hak konstitusi dan hak asasi manusia. Terdapat perbedaan penegakan hukum di negara maju dan negara berkembang, namun demikian baik negara maju maupun negara berkembang telah berusaha untuk melindungi kepentingan warga negaranya untuk menikmati lingkungan yang sehat sekaligus melindungi hak lingkungan. Kedua, persamaan dan perbedaan yang terjadi diantara empat negara berkembang dan satu negara maju disebabkan karena adanya perbedaan political will di masing-masing negara. Selain itu kebijakan hukum ini juga dipengaruhi oleh adanya situasi dan kondisi masing-masing negara yang berbeda, baik berkaitan dengan aparat penegak hukum, kesadaran masayarakat dan juga kelembagaan yang dimiliki oleh masing-masing negara.

\section{Daftar Pustaka}

\section{Buku}

Asshiddiqie, Jimly, Green Constitution: Nuansa Hijau Undang-Undang Dasar Negara Republik Indonesia Tahun 1945, Rajawali Pers, Jakarta, 2010.

Konstitusi Ekonomi, 2010, PT Kompas Media Nusantara, Jakarta.

Ahmad Santosa, Mas, Greener Constitution: Solusi Strategis Pengarusutamaan Pembangunan Berkelanjutan Berwawasan Lingkungan, Makalah, Materi Amandemen UUD negara RI 1945, 2009. , Good Governance Hukum Lingkungan, ICEL, Jakarta.

Muhammad Akib, 2014, Hukum Lingkungan Perspektif Global Dan Nasional, Edisi Revisi, Rajawali Pers, Jakarta, 2001.

, Politik Hukum Lingkungan: Dinamikan Dan Refleksinya Dalam Produk Hukum Otonomi Daerah, PT RajaGrafindo Persada, Jakarta, 2012. 
Soemarwoto, Otto, Ekologi, Lingkungan Hidup dan Pembangunan, Djambatan, Bandung, 1991.

\section{Jurnal}

de Bolívar Maura, Mullen, "A Comparison of Protecting the Environmental Interests of Latin- American Indigenous Communities from Transnational Corporations Under International Human Rights and Environmental Law" J. Transnat'l L. E Pol'y, (Fall, 1998).

Ijaiya, Hakeem, Environmental Rights In Nigeria And India. International Journal of Environmental and Development (IJED) Vol. 9 (2).

Kalas Peggy, Rodgers, The Implications of Jota V. Texaco and the Accountability of Transnational Corporations, Vol. 12. Pace Int'l L. Rev.(2000).

Sudhir K., Chopra, "Multinational Corporations in the Aftermath of Bhopal: The Need for a New Comprehensive Global Regime for Transnational Corporate Activity", Vol. 29, Val. U. L. Rev., (Fall, 1994)

Sukanya, Pillay, "Absence of Justice: Lessons from The Bhopal Union Carbide Disaster for Latin America", Vol. 14, Mich. St. J. Int'l L, (2006).

\section{Website}

Bharat H., Desai, and Sidhu, Balraj "On the Quest for Green Courts In India", law.pace.edu/sites/default/files/IJIEA/jciDesai_India_3-17_cropped.pdf. Diakses tanggal 16 Maret 2015.

Brind, Kumar, et. all, "Brief Review of the Legislative Aspects of Noise Pollution "http://home.uchicago.edu/ mstaisch/Sharad/papers/Legislative\%20As pects\%20of\%20Noise\%20Pollution.pdf, Diakses tanggal 5 Oktober 2014.

Butt, Simon "Traditional Land Rights Before the Indonesian Constitutional Court "Law and Environment Development Journal. http://www.leadjournal.org/content/14057.pdf Diakses tanggal 3 Maret 2015.

Don, Mayer and Jebe Ruth, "The Legal And Ethical Environment For Multinational Corporations",http://www.enterpriseethics.org/portals/0 /pdfs/good_business_chapter_13.pdf. Diakses tanggal 24 April, 2015.

Dutta, Sanjib, "The Bhopal Gas Tragedy", http://www.econ.upf.edu/ lemenestrel/IMG/pdf/bhopal_gas_tragedy_dutta.pdf, Dialses tanggal 13 September, 2015.

Finland Environmental Act, 2000. https://www.finlex.fi/en/laki/kaannokset /2000/en20000086.pdf. Dakses tanggal 28 Desember 2014.Ritva Jolkkonen, "Public involvement in environmental issues in the ASEM - background and Overview", 
http://supremecourtofindia.nic.in/speeches/speeches_2009/judicial_activism_tc d_dublin_14-10-09.pdf. Diakses tanggal 12 September 2014.

India Constitution, http://www.cgsird.gov.in/constitution.pdf. Diakses 14 September 2014.

Indian Company Act, http://www.mca.gov.in/Ministry/pdf/ CompaniesAct2013.pdf. Diakses Tanggal 5 Oktober 2014.

K.G., Balakrishnan, "Judicial Activism under the Indian Constitution", Center for Economic and Social Rights, 1999, http://www.cesr.org/downloads/ Recognizing\%20the\%20Right $\% 20$ to\%20Health\%20in\%20Ecuador.pdf. Diakses 12 September 2014.

Karlheinz, Spitz and Yahya Husin "The AMDAL Process and the Equator Principles Common themes and apparent differences", PUBLIC\%20PARTICIPATION\%202/AMDAL\% 20PAPER.pdf. Diakses tanggal 16 April 2015.

Khatri Upasana "Indigenous Peoples' Right to Free, Prior, and Informed Consent in the Context of StateSponsored Development: The New Standard Set by Sarayaku V; Ecuador and its Potential to Delegitimize the Belo Monte Dam Upasana Khatri American University Washington College of Law."http://digitalcommons.wcl.american.edu/cgi/viewcontent.cgi ?article $=1805 \&$ context=auilr. . Diakses 22 Mei 2015.

Maria Clara, Galvis, "The Right of Indigenous Peoples to Prior Consultation", http://www.oxfamamerica.org/static/media/files/the-right-ofindigenous-people-to-prior-consultation-exec-summary.pdf. Diakses tanggal 24 April, 2015.

Michael and Niessen Nicole, " Environmental Law and Development Lessons from the Indonesian Experience. http://www.untagsmd.ac.id/files/Perpustakaan_Digital_ 1/ENVIRONMENTAL\%20LAW INDONESIA \%20Environmental\%20law $\% 20$ in $\% 20$ development $\% 20 \% 20$ le. Diakses tanggal 4 Maret 2015.

National Green Tribunal Act 2010, http://faolex.fao.org/docs/pdf/ind98219.pdf, diakses 8 Oltober 2014.

Otubu, www.unilag.edu.ng, akses 14 Juni 2014

Patra Swapan, Kumar and Khrisna V.V., "National Green Tribunal and Environmental Justice in India", http://www.niscair.res.in/jinfo /ijms/ijms-forthcoming-articles/IJMS-PR-April\%202015/MS\%202615\% 20Edited.pdf. Diakses tanggal 26 desember, 2014.

The Environment Protection Act 1986, http://envfor.nic.in/ legis/env/eprotect_act_1986.pdf. Diakses tanggal 26 September, 2014.

Thomas C., Beierle, "Public Participation in Environmental Decisions: An Evaluation Framework Using Social Goals". http://www.rff.org 
/files/sharepoint/WorkImages/Download/RFF-DP-99-06.pdf. Diakses Tanggal 24 Mei 2015.

Tihinen, Taimo, Significant Mining Incident in Finland", http://www.hsa.ie/eng/Your_Industry/Mining/Head_of_State_Mining Authorities_Meetings/PDF-Tihinen-Taimo-SIGNIFICANT-MININGINCIDENTS-IN-FINLAND. Diakses Tanggal 23 Pebruari 2015.

UNDP, "Assessment of Development Results Indonesia Evaluation of UNDP Contribution", http://www.oecd.org/derec/undp/47865010.pdf, Diakses tanggal 12 Pebruari 2015.

UNEP, " Analysis of formalization approaches in the artisanal and small-scale gold mining sector based on experiences in Ecuador, Mongolia, Peru, Tanzania and Uganda A compendium of case studies". http://www.unep.org/chemicalsandwaste/ Portals/9/Mercury/Documents /ASGM/Formalization_ARM/Case\%20Studies\%20Compendium\%20June \%202012.pdf. Diakses pada tanggal 26 Mei 2015.

Woldemelekot Workabeba Belkele, "Liability of Transnational Corporations for Indegenous Peoples Human Rights Violation", Master Thesis, www.fao.org/3/a-i0970e/i0970e01e.pdf 